\title{
Developing SMART Goals for Your Organization'1
}

Henry M. Cothran and Allen F. Wysocki

"You've got to be very careful if you don't know where you're going, because you might not get there." - Yogi Berra

"Goal setting is one of the basic tools used by organizations to assist in setting a direction and achieving it. Successful organizations often set longand short-term goals for service development, improving quality, reducing errors, becoming more customer-focused, and building better internal and public relations." - Jeffery Davis, Managing and Achieving Organizational Goals

Individuals may set goals to achieve a personal objective such as career advancement. This publication is designed to introduce a sequential process for setting goals. It begins by defining a goal and identifying reasons for setting goals. It then describes a process based on the acronym SMART for developing and implementing goals.

\section{Defining "Goal"}

A goal is a statement of a desired future an organization wishes to achieve. It describes what the organization is trying accomplish. Goals may be strategic (making broad statements of where the organization wishes to be at some future point) or tactical (defining specific short-term results for units within the organization). Goals serve as an internal source of motivation and commitment and provide a guide to action as well as a means of measuring performance (Barton, 2000). Defining organizational goals helps to conceptualize and articulate the future direction of the organization, thus allowing those responsible for setting that direction to develop a common understanding of where the organization is heading. Goals provide a way of assuring that an organization will get where it wants to go.

\section{Setting Goals}

How goals are set is as important as the goal itself. Thus it is important that goals meet specific criteria that can be used to easily assess them. One way of doing this is to use the acronym "SMART" as a way of evaluating the goal. An internet search for "SMART" goals yielded some 6.7 million hits. One of those hits, Measure-X.com said that "the origin of the acronym is lost, and the specific traits are not universally agreed upon, [but] SMART goals still provide a great framework to improve your goal setting and help you create more effective goals." A further search of the first forty websites found that most used the following words to define a

"SMART" goal:

1. This is EDIS document FE577, a publication of the Department of Food and Resource Economics, Florida Cooperative Extension Service, Institute of Food and Agricultural Sciences, University of Florida, Gainesville, FL. Published November 2005. Please visit the EDIS website at http://edis.ifas.ufl.edu.

2. Henry M. Cothran, Associate-In, and Allen F. Wysocki, Associate Professor, Department of Food and Resource Economics, Florida Cooperative Extension Service, Institute of Food and Agricultural Sciences, University of Florida, Gainesville, FL.

The Institute of Food and Agricultural Sciences (IFAS) is an Equal Opportunity Institution authorized to provide research, educational information and other services only to individuals and institutions that function with non-discrimination with respect to race, creed, color, religion, age, disability, sex, sexual orientation, marital status, national origin, political opinions or affiliations. U.S. Department of Agriculture, Cooperative Extension Service, University of Florida, IFAS, Florida A. \& M. University Cooperative Extension Program, and Boards of County Commissioners Cooperating. Larry Arrington, Dean 
- Specific

- Measurable

- Attainable

- Relevant

- Time-bound

\section{Specific}

A goal is specific when it provides a description of what is to be accomplished. A specific goal is a focused goal. It will state exactly what the organization intends to accomplish. While the description needs to be specific and focused, it also needs to be easily understood by those involved in its achievement. It should be written so that it can be easily and clearly communicated. A specific goal will make it easier for those writing objectives and action plans to address the following questions:

- Who is to be involved?

-What is to be accomplished?

-Where is it to be done?

- When is it to be done?

\section{Measurable}

A goal is measurable if it is quantifiable. Measurement is accomplished by first obtaining or establishing base-line data. It will also have a target toward which progress can be measured, as well as benchmarks to measure progress along the way. A measurable goal will answer questions such as:

- How much?

- How many?

- How will you know when it is accomplished?

\section{Attainable}

There should be a realistic chance that a goal can be accomplished. This does not mean or imply that goals should be easy. On the contrary, a goal should be challenging. It should be set by or in concert with the person responsible for its achievement. The organization's leadership, and where appropriate its stakeholders, should agree that the goal is important and that appropriate time and resources will be focused on its accomplishment. An attainable goal should also allow for flexibility. A goal that can no longer be achieved should be altered or abandoned.

\section{Relevant}

Goals should be appropriate to and consistent with the mission and vision of the organization. Each goal adopted by the organization should be one that moves the organization toward the achievement of its vision. Relevant goals will not conflict with other organizational goals. As noted earlier, goals are set by or in concert with the person responsible for achievement. It is important that all short-term goals be relevant (e.g., consistent) with the longer-term and broader goals of the organization.

\section{Time-bound}

Finally a goal must be bound by time. That is, it must have a starting and ending point. It should also have some intermediate points at which progress can be assessed. Limiting the time in which a goal must be accomplished helps to focus effort toward its achievement.

\section{References}

Barton, R.B. 2000. Chapter 7, Organizational Goal Setting and Planning. Murray State University, Murray, KY.

http://campus.murraystate.edu/academic/faculty/ rb.barton/40mgmt07.ppt\#256,1,chapter7.

Davis, Jeffery H. N/D. Chapter 1, Managing and Achieving Organization Goals. American Management Association, New York, NY. http://www.flexstudy.com/catalog/ index.cfm?location $=$ sch \& coursenum $=95086$.

Measure-X. S.M.A.R.T. Goals. N.D. E-mail Newsletter \#27, Phoenix, AZ. http://www.measure-x.com/newsletter/27.html. 